\title{
Early detection of folic acid deficiency in elderly patients
}

\author{
C. G. L. RAPER AND M. CHOUDHURY \\ From the Departments of Haematology and Geriatrics, Kingston General Hospital, Hull, UK
}

SUMMARY Folic acid deficiency is very common in elderly patients who have a mean red cell volume greater than $94 \mathrm{fl}$. Eighteen out of 40 elderly patients with red cell macrocytosis who initially had normal red cell folate and serum B12 levels subsequently developed folic acid deficiency.

Nutritional folic acid deficiency is very common in elderly patients (Varadi and Elwis, 1966) and an inadequate intake of folic acid may precede the onset of anaemia by several months. The red cell folate level is a more reliable index of body stores of folic acid than is the serum folate level (Herbert, 1962). An increase in the mean red cell volume (MCV) occurs in folic acid deficiency but also in pernicious anaemia, sideroblastic anaemia, myeloma, marrow aplasia, myxoedema, liver disease, haemolytic anaemia, excessive alcohol intake (Chanarin, 1976), and chronic obstructive airway disease (O'Neill et al., 1972). We have assessed the value of the MCV as a screening test for folic acid deficiency in a group of acute geriatric admissions. We have also followed up some of those patients who initially had a raised MCV and no evidence of folic acid deficiency to see whether the raised MCV preceded other evidence of folic acid deficiency.

\section{Patients}

Soon after admission to an acute geriatric unit $\mathbf{4 0 0}$ inpatients were studied. The haemoglobin level, mean red cell volume, serum B12, and red cell folate levels were recorded. As we were attempting to assess the likelihood of finding a low red cell folate or serum B12 at any given MCV the patients were not selected randomly. The Figure shows that the majority of the patients studied had an MCV near the upper limit of the normal range. No attempt was made to determine the incidence of folic acid deficiency in a random population of old people.

Forty patients (18 men and 22 women) who had a raised MCV but normal serum B12 and red cell folate levels on admission were followed up for six

Received for publication 13 July 1977 months. Clinical history and laboratory investigation included inquiry into alcohol intake, evidence of respiratory failure, thyroid and liver function tests, and repeat serum B12 and red cell folate assays. The MCV was recorded at intervals and a bone marrow aspiration was carried out in 25 cases.

In a separate study the haemoglobin and MCV were recorded on 300 consecutive acute geriatric admissions.

\section{Methods}

Haemoglobin levels and mean red cell volumes were determined on the Coulter ' $S$ '. The MCV potentiometer was adjusted to give a mean MCV of $89 \mathrm{fl}$ and a range of $82-96 \mathrm{fl}( \pm 2 \mathrm{SD})$ when a group of 250 blood donors for open-heart surgery was studied. Red cell folate levels were measured by radioassay using beta-lactoglobulin as the folate-binding protein (Schreiber and Waxman, 1974) and serum B12 levels by a radioisotope assay using normal serum as the binding protein (Britt et al., 1969). The normal range of the serum B12 was $160-925 \mathrm{pg} / \mathrm{ml}$ and of the red cell folate $170-1000 \mathrm{ng} / \mathrm{ml}$ packed red cells when a group of 100 blood donors was studied.

\section{Results}

The Figure shows that of the 143 patients with an MCV below $95 \mathrm{fl}, 16(11.2 \%)$ had either a low red cell folate or a low serum B12, and of the 257 patients with an MCV of $95 \mathrm{fl}$ and above, 167 $(64.5 \%)$ had either a low red cell folate or a low serum B12.

Of the $\mathbf{4 0 0}$ geriatric in-patients studied, $\mathbf{1 5 6}$ had a red cell folate below $170 \mathrm{ng} / \mathrm{ml}$, and 27 patients had a serum B12 below $160 \mathrm{pg} / \mathrm{ml}$ with a normal red cell 


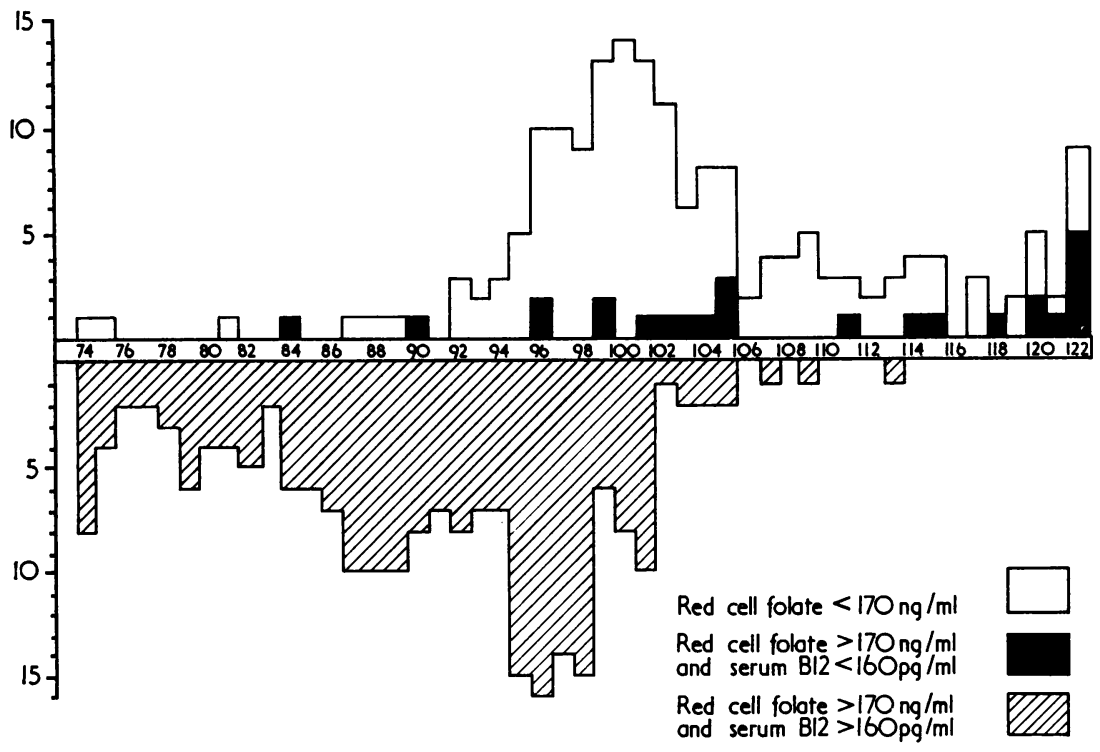

Figure The mean red cell volume (MCV), the red cell folate, and serum $B_{12}$ levels of 400 acute geriatric admissions.

folate. The haemoglobin levels of these patients ranged from $4.5 \mathrm{~g} / \mathrm{dl}$ to $16.5 \mathrm{~g} / \mathrm{dl}$ (mean $10.4 \mathrm{~g} / \mathrm{dl}$ ). They were considered to have either B12 or folic acid deficiency and the appropriate investigations and therapy were carried out.

Of the 400 geriatric in-patients studied, 217 had both a normal red cell folate and serum B12 level and their haemoglobin levels ranged from $6.3 \mathrm{~g} / \mathrm{dl}$ to $17.5 \mathrm{~g} / \mathrm{dl}$ (mean $11.4 \mathrm{~g} / \mathrm{dl}$ ).

However, of the 40 patients who had a raised MCV ranging from $97 \mathrm{fl}$ to $109 \mathrm{fl}$ (mean $101 \mathrm{fl}$ ), but normal red cell folate and serum B12 on admission, 18 developed folic acid deficiency during the following six months. The diagnosis of folic acid deficiency was made by showing that the red cell folate level fell to below the lower limit of normal and that there was megaloblastic erythropoiesis in the 12 patients who had bone marrow biopsies. The initial haemoglobin levels of these patients ranged from $9.6 \mathrm{~g} / \mathrm{dl}$ to $14.8 \mathrm{~g} / \mathrm{dl}$ (mean $12.7 \mathrm{~g} / \mathrm{dl}$ ). Of the remaining 22 patients who had a raised MCV but a normal red cell folate and serum B12 on admission, the MCV returned into the normal range in 10 patients, severe long-standing emphysema was present in five patients, there was a history of chronic alcoholism in three patients, and there was one case each of myxoedema, sideroblastic anaemia, haemolytic anaemia, and pernicious anaemia. The initial haemoglobin levels of these patients ranged from $8.0 \mathrm{~g} / \mathrm{dl}$ to $15 \cdot 7 \mathrm{~g} / \mathrm{dl}$ (mean $13 \cdot 1 \mathrm{~g} / \mathrm{dl}$ ).

Of the 300 consecutive geriatric admissions 37 $(12 \%)$ had an MCV above $96 \mathrm{fl}$.

\section{Discussion}

As the red cell indices are now readily available it is important to know what significance should be attached to a mean red cell volume just above the normal range, especially as we found that $12 \%$ of all geriatric admissions have an MCV above the range of a healthy population. As it is impracticable to carry out bone marrow examination on all these patients a red cell folate and a serum B12 estimation should be the initial investigations. We have shown that when the MCV is above $94 \mathrm{fl}$ it is very likely that there is either folic acid or vitamin B12 deficiency and that the haemoglobin level does not help in separating these patients from normals. Follow-up of those patients with a modest increase in the MCV but with a normal red cell folate and serum B12 on admission has shown that nearly half will develop folic acid deficiency if untreated. The remainder either have some well-recognised cause for their red cell macrocytosis or their MCV returns into the normal range.

In folic acid deficiency red cell macrocytosis is the earliest change in the peripheral blood, occurring well before a significant fall in the haemoglobin level. The Coulter Counter measures the MCV directly and can be accurately calibrated to give reproducible results over a long period of time. Although a reduction in the serum folate is the first indication of a negative folate balance it is too sensitive to be used as an indicator of progressive folic acid deficiency, and about one-third of all acute geriatric admissions 
have been shown to have subnormal serum folate levels (Hurdle and Williams, 1966). A low red cell folate is considered unequivocal evidence of folate deficiency but a normal concentration can be encountered in some folate deficient patients because of the lag needed to replace cells of higher folate content by those with low folate. This would explain why nearly half of those patients with a moderately raised MCV and initially normal red cell folate eventually developed a megaloblastic marrow and a subnormal red cell folate. It is suggested that all geriatric patients with an MCV of greater than $94 \mathrm{fl}$ should be followed up for at least six months to exclude folic acid deficiency.

We thank Dr. S. R. Datta, Dr. P. Horrocks, and Dr. J. Knox for allowing us to study patients under their care, and the Radio Isotopes Department, Hull Royal Infirmary (Sutton) for carrying out the serum $\mathrm{B} 12$ and red cell folate estimations.

\section{References}

Britt, R. P., Bolton, F. G., Cull, A. C., and Spray, G. H. (1969). Experience with a simplified method of radioisotopic assay of serum vitamin B12. British Journal of Haematology, 16, 457-464.

Chanarin, I. (1976). Clinics in Haematology, 5, (3).

Herbert, V. (1962). Experimental nutritional folate deficiency in man. Transactions of the Association of American Physicians, 75, 307-320.

Hurdle, A. D. F., and Williams, T. C. P. (1966). Folicacid deficiency in elderly patients admitted to hospital. British Medical Journal, 2, 202-205.

O’Neill, B. J., Marlin, G. E., and Streeter, A. M. (1972). Red Cell Macrocytosis in chronic obstructive airway disease (Letter). Medical Journal of Australia, 1, 283.

Schreiber, C., and Waxman, S. (1974). Measurement of red cell folate levels by ${ }^{3} \mathrm{H}$-pteroylglutamic acid radioassay. British Journal of Haematology, 27, 551-558.

Varadi, S., and Elwis, A. (1966). Folic acid deficiency in the elderly (Letter). British Medical Journal, 2, 410. 